\title{
Effect of Caffeine on Coughing in Children Aged 3-36 Months: A Randomized Clinical Trial
}

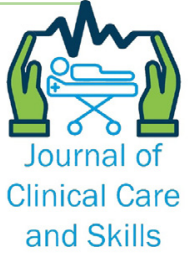

\section{ARTICLE INFO}

\section{Article Type}

Original Research

\section{Authors}

Tagrian Esfahani M. ${ }^{1} M D$,

Keshavarz K. ${ }^{* 2} M D$,

Keshtkari A. ${ }^{3} M D$,

Sadeghi Mansourkhani $\mathrm{H}^{4} \mathrm{PhD}$,

Akbartabar Toori M. ${ }^{5} P h D$

Zoladl M. ${ }^{5} \mathrm{PhD}$

\section{How to cite this article}

Tagrian Esfahani M, Keshavarz K

Keshtkari A, Sadeghi Mansourkha-

ni H. Effect of Caffeine on Coughing

in Children Aged 3-36 Months: A

Randomized Clinical Trial. Journal

of Clinical Care and Skills. 2020 1(2):81-87.

\section{A B S T RA C T}

Aims Coughing is one of the most common clinical complaints in pediatric medicine. Since caffeine, as a central nervous system stimulant from methylxanthine, inhibits tumor necrosis factor-alpha $(\mathrm{TNF} \alpha)$ and leukotriene synthesis and reduces inflammation and initiates the immune process, the aim of this study was to determine the effect of caffeine on on coughing in children aged 3-36 months.

Materials and Methods In this randomized clinical trial study in 2015, among children referred to the Shahid Mofateh Pediatric Clinic of Yasuj, 120 children aged 3-36 months with bronchiolitis coughing, lower respiratory viral disease, increased airway sensitivity, or moderate persistent asthma were selected by available sampling method. They were assigned in intervention (reciving salbutamol and caffeine) and control (reciving salbutamol alone) groups by quadratic block randomization. In addition to completing demographic information at the beginning of the study, data on daily and nocturnal cough at the beginning of the study, 48 hours, 1 week, and 2 weeks after starting the drug were recorded. The data were analyzed by SPSS 21 software, using Mann-Whitney test, Chi-square or Fisher's exact test, generalized estimating equation, Friedman, and Wilcoxon statistical tests.

Findings Daily cough and nocturnal cough significantly decreased in the intervention group at 48 hours, 1 and 2 weeks after beginning the treatment $(\mathrm{p}<0.05)$.

Conclusion Prescription of caffeine with salbutamol is effective in accelerating improvement of cough in children.

Keywords Caffeine; Wheezing; Cough; Child
${ }^{1}$ Student Research Committee, Yasuj University of Medical Sciences, Yasuj, Iran

${ }^{2}$ Pediatric Cardiology Department, Medicine Faculty, Shiraz University of Medical Sciences, Shiraz, Iran ${ }^{3}$ Pediatric Medicine Department, Medicine Faculty, Yasuj University of Medical ciences, Yasuj, Iran ${ }^{4}$ Medicinal Plants Research Center, Yasuj University of Medical Sciences, Yasuj, Iran

${ }^{5}$ Social Determinants of Health Research Center, Yasuj University of Medical Sciences, Yasuj, Iran

\section{Correspondence}

Address: Pediatric Cardiology Department, Namazi Hospital, Shiraz University of Medical Sciences, Zand Blvd., Shiraz, Iran. Postal Code: 7193613311

Phone: +98 (71) 36474298

Fax: +98 (71) 36474298

kmbz_ped86@yahoo.com

\section{Article History}

Received: November 6, 2018

Accepted: January 28, 2019

ePublished: June 20, 2020

\section{I T A T I O N L I N K S}

[1] Nelson textbook of ... [2] The pathogenesis of respiratory syncytial virus disease in ... [3] Respiratory syncytial ... [4] Rates of hospitalization for respiratory syncytial virus infection among children ... [5] Bronchiolitis-associated hospitalizations among US children ... [6] Down syndrome: a novel risk factor for respiratory syncytial virus bronchiolitis-a prospective ... [7] Respiratory syncytial virus: the virus, the disease and the ... [8] Respiratory syncytial virus and parainfluenza ... [9] Respiratory syncytial virus and influenza A infections in ... [10] The correlation factor about respiratory syncytial virus bronchiolitis and post-bronchiolitis wheezing in ... [11] Risk factors in children hospitalized with RSV bronchiolitis ... [12] Report on a national institute of allergy and infectious diseases -sponsored workshop on the genetics of total immunoglobulin E levels in ... [13] Wheezing in infants and toddlers: new ... [14] Singledose slow-release aminophylline at night prevents ... [15] The respiratory tract in pediatric critical illness and ... [16] The Harriet Lane ... [17] Caffeine for ... [18] Fanaroff and Martin's Neonatal-perinatal medicine ... [19] Effects of salbutamol and caffeine ingestion on exercise metabolism ... [20] Caffeine intake and asthma ... [21] Severe respiratory syncytial virus bronchiolitis in infancy and asthma and allergy at... [22] Seasonality of long term wheezing following respiratory syncytial virus lower respiratory ... [23] Lack of effect of zinc sulfate on wheezing after bronchiolitis in infants less than two ... [24] Chronic cough and how to deal ... [25] The effect of dietary components on inflammatory lung diseases-a literature ... [26] Antiinflammatoryeffectofcaffeineisassociatedwith improvedlungfunctionafterlipopolysaccharideinduced ... [27] Cough model in the rats induced by $10 \%$ citric citric acid ... [28] Study of realationship between social support and parents satisfaction of provided care for premature infants in selected hospitals of Tehran University of Medical ... [29] Comparison study of therapeutic effect of dextrometorphan and essence of Thyme (Zatara Multiflorian) in acute and non-productive ... [30] The effect of combination of Zingeber and Althea officinalis extracts in ... [31] Honey plus coffee versus systemic steroid in the treatment of persistent post-infectious cough: a randomised ... 


\section{Introduction}

Coughing in children is one of the major issues in pediatric medicine, which can be due to gastroovarian reflux, aspiration of a substance, contact with allergens in allergic children and viral diseases of the lower respiratory system [1].

The respiratory sensory viral (RSV) virus is a RNA virus of the Paramyxoviridae family and the Pneumoviridae subfamily, which can cause a wide range of clinical symptoms from a mild respiratory infection to severe bronchiolitis and pneumonia $[2,3]$. The virus is the most common cause of lower respiratory infection in children younger than one year, and approximately 1-3\% of these patients need hospitalization $[4,5]$. The infants with preterm birth, and those with chronic pulmonary diseases due to pre-maturity, congenital heart disease, cystic fibrosis, immunodeficiency diseases and Down syndrome are more at risk for severe RSV infection $[6,7]$.

After an acute bronchiolitis, $75 \%$ of children develop recurrent symptoms of lower respiratory tract infection. In a large group, the symptoms, such as cough disappear until the school age, but bronchioles disorder can be diagnosed at least until the age of $13[8,9]$.

In the bronchiolitis of bronchioles, the lungs are inflamed and full of debris (dead cells), which causes narrowing of the airways and prevents the air from passing through, resulting in severe coughing and short respiration by reducing the oxygen saturation [10-12]. For this reason, Bronchodilator, such as salbutamol, aminophylline and theophylline (methylhexanthines), are prescribed to relax the muscles of the bronchus and dilated bronchus [13], which the outcome is not predictable without considering the underlying reason ${ }^{[14]}$.

In addition to the mentioned drugs, antiinflammatory drugs can also affect the airway inflammation and the duration of symptoms of bronchiolitis. It has been reported that $4 \mathrm{~h}$ after oral administration of high doses of dexamethasone, respiratory symptoms in infants have been improved [15].

Caffeine is a central nervous system stimulant from Methylxanthines with a serum toxicity level greater than $50 \mathrm{mg} / \mathrm{L}$, which in addition to reducing physical fatigue and increasing concentration inhibits alpha-free tumor necrosis factor $(\mathrm{TNF} \alpha)$ and leukotriententase and reduces inflammation and initiates immunity. Its effects last approximately one hour after consumption, and its median dose decreases in the body after 3 to $4 \mathrm{~h}$. The half-life of caffeine is between 3 and $7 \mathrm{~h}$, which is metabolized in the liver by cytochrome p450 oxidase enzyme, and each of its metabolites is excreted by the urine [16].

Despite the above theoretical considerations, for the therapeutic use of caffeine in this study, it is essential to provide evidences indicating the benefits of this intervention compared with the related side effects and also no disadvantage of the combination of caffeine and medications used for cough in order to avoid the conventional treatments in children.

The role of caffeine available in tea, coffee, and cola drinks is known to regulate sleep and respiration, and to improve nocturnal asthma coughing and spirometric status [17]. In addition, in pediatric medicine, caffeine is used to treat apnea of prematurity, because theophylline it effective as caffeine with less side effects [18].

Also, in studies that examined the effect of salbutamol and caffeine intake on blood lactate, growth hormone and plasma insulin levels, no side effects of salbutamol and caffeine have not been reported, suggesting that the use of these two drugs is not accompanied by an absolute prohibition [19].

All these considerations into account, and since in the few studies conducted on the therapeutic effects of caffeine in caffeinated drinks, further studies are needed to obtain further evidence of caffeine's therapeutic efficacy [17, 20]. On the other hand, previous studies examined the effectiveness of drugs, such as dextromethorphan and herbal compounds, like thyme extract, honey, and others on coughing with contradictory results [21, 22]; the present study was conducted to determine the effect of caffeine on coughing in children aged 3-36 months.

\section{Material and methods}

This randomized clinical trial was done on children referred to the Shahid Mofateh Pediatric Clinic of Yasuj, Iran in 2015 and was approved by the Research Ethics Committee (Ethics code IR.YUMS.REC.1394.172) and registered at Iranian registry of clinical trials (IRCT2016041727444N1).

At the beginning of the study, using the results of Abbasi et al. [23] and considering the alpha value of 0.05 (95\% confidence level), beta of $20 \%$ ( $80 \%$ test power) and the effect size of 0.25 between the ratios of the two groups and also $15 \%$ probability of falling, the sample size was estimated 68 subjects in each group and 136 subjects overall. Then, through the random allocation of the quadruple block, a number from one to 136 was assigned to one of the intervention or control groups and a random block allocation list was determined.

The researcher responsible for collecting the data, referred to the considered clinic in Yasuj, Iran and using available sampling method selected the patient with inclusion criteria, including the age of 3 to 36 months, coughing due to bronchiolitis, viral diseases of the lower respiratory tract, increased airway sensitivity or mild steady asthma, and the ability to eat drugs. Their demographic and field characteristics were recorded in a research checklist 
and were given to a pediatrician. After examination of each child and recording the information about the daily and nocturnal cough and also the results of physical examination according to the exclusion criteria, including dyspnea, inadequate respiratory rate with age, nasal flutter, severe chest tightness, abnormal movements of the chest and abdomen while inhalation, pneumonia, immunodeficiency, seizure, cardiovascular diseases and digestive disorders were recorded in the checklist by the physician, their families re-returned to the researcher responsible for collecting the data. He excluded the children who had the exclusion criteria by checking out the checklists completed by the pediatrician and only explained for their families how to care their children to improve their condition for $5 \mathrm{~min}$.

The researcher made the families of the children who met the inclusion and exclusion criteria and were selected as the subjects about the research objectives and methods and also the benefits and side effects of the drugs used in the study. After answering their questions and ambiguities, they found that their child is randomly assigned to one of the intervention or control groups and were provided with the written informed consent. After completing the informed written consent form by the legal guardians of each child, a number was assigned to each child according to the time of referral and observance of the priority of entry, which was matched with a block random allocation list and they were allocated to the intervention or control group.

Children in the control group received salbutamol, while children in the intervention group, in addition to salbutamol for 5 days, received caffeine $10 \mathrm{mg} / \mathrm{kg}$ body weight daily ${ }^{[18]}$ in two divided doses in the morning and evening.

All children participating in the study were reexamined by a pediatrician $48 \mathrm{~h}$, one week and two weeks after taking medications and their daily and nocturnal cough rates were recorded in the research checklist.

During the data collection, 16 children were excluded from the study; in the control group, 2 patients due to the absence in follow-up, 3 patients as diagnosed with pneumonia and 3 patients as diagnosed with moderate persistent asthma; in the intervention group, 1 patients due to the absence in follow-up, 3 patients due to stop in intervention because of nausea and vomiting as the side effects of caffeine and also 4 patients due to drug use at a dose less than the prescribed dose or no drug intake at the specified time were excluded from the study. Therefore, the data collected for 120 children in each group (60 in each group) were analyzed.

In this triple-blind study, the number of each child in the randomized block allocation, which indicated that he belonged to the intervention or control group and except for the researcher responsible for data collection, no one else was not informed was recorded as an identification code on research checklist. The pediatrician was not informed that the child is belonged to the intervention or control group, had no access to the information recorded in the previous stages and according to the research protocol, in each follow-up, without questioning with the patient's companion about prescription drugs, only to examine the recovery process and record the daily and nocturnal cough of the patient. At the end of each session, he transferred the completed research checklist to the researcher who collected the data. Also the pharmacist cooperating with the research team was unaware of the results of basic examinations of children, and did not have any relationship with them after delivering the drugs to the children's parents. The statistician was also blind to the code assigned to intervention and control groups until the end of the analysis.

In this research, all ethical considerations, such as obtaining the informed consent of the legal authorities of the samples and making them sure about the possibility of withdrawal from the study for those who are not willing to continue to participate in the study, the confidentiality of all collected information and their use in general and for study objectives, no changes in the drugs used, no deprivation of patient's from standard treatment and care and no imposed additional costs to contributors to the research and insurance organizations were observed.

Data analysis was performed using SPSS 21 software at $95 \%$ confidence level. At the baseline, the MannWhitney $U$ test was used to compare the quantitative variables, including age and the number of family members, which showed no normal distribution. Comparison of frequency distribution of the background and dependent qualitative variables between the studied groups at the baseline was performed using Chi-square test or Fisher's exact test.

To compare the difference in daily and nocturnal cough $48 \mathrm{~h}$, one week and two weeks after the intervention between the intervention and control groups (intergroup comparison), Generalized Estimation Equations (GEE) were used. Comparison of the difference between the above dependent variables at the baseline, $48 \mathrm{~h}$, one week and two weeks after the interventions was done using Friedman and Wilcoxon statistical tests, according to the studied groups (intra-group comparison).

\section{Findings}

The mean age of children was $13.3 \pm 8.8$ months and mean family members of them was $3.8 \pm 0.8$. The mean age in the control and intervention groups was $13.2 \pm 8.7$ and $13.4 \pm 9.1$ months and the mean family members in the control and intervention groups was $3.9 \pm 0.8$ and $3.8 \pm 0.8$ people, respectively, which there was no significant difference between two 
groups ( $p>0.05)$.

There were no significant differences between the intervention and control groups at the baseline in terms of background and demographic qualitative variables and daily and nocturnal cough rates $(\mathrm{p}<0.05$, Tables 1 and 2).

Table 1) Comparison of the absolute and relative distributions of qualitative demographic and background variables in the children in the interventional group (60 subjects) and control ( 60 subjects) at baseline (numbers in parentheses are percentages)

\begin{tabular}{|c|c|c|c|}
\hline Variables & $\begin{array}{l}\text { Intervention } \\
\text { group }\end{array}$ & $\begin{array}{l}\text { Control } \\
\text { group }\end{array}$ & $P$ value \\
\hline $\begin{array}{l}\text { Gender } \\
\text { Male } \\
\text { Female }\end{array}$ & $\begin{array}{l}29(48.3) \\
31(51.7)\end{array}$ & $\begin{array}{l}27(45.0) \\
33(55.0)\end{array}$ & 0.71 \\
\hline $\begin{array}{l}\text { Family monthly } \\
\text { income, Million } \\
\text { Toman } \\
<1 \\
1-3 \\
>3\end{array}$ & $\begin{array}{c}21(35.0) \\
36(60.0) \\
3(5.0)\end{array}$ & $\begin{array}{c}27(45.0) \\
31(51.7) \\
2(3.3)\end{array}$ & 0.58 \\
\hline $\begin{array}{l}\text { History of disease } \\
\text { Family history of } \\
\text { asthma } \\
\text { Family history of }\end{array}$ & $5(8.3)$ & 7 (11.7) & 0.54 \\
\hline $\begin{array}{l}\text { food allergy } \\
\text { Family history of }\end{array}$ & $5(8.3)$ & $6(10.0)$ & 0.75 \\
\hline $\begin{array}{l}\text { Family history of } \\
\text { inhalation allergy }\end{array}$ & $26(43.3)$ & $\begin{array}{c}0 \\
21(35.0)\end{array}$ & $\begin{array}{l}0.15 \\
0.35\end{array}$ \\
\hline $\begin{array}{l}\text { History of exposure } \\
\text { to smoking }\end{array}$ & $17(28.3)$ & $16(26.7)$ & 0.84 \\
\hline $\begin{array}{l}\text { History of atopic } \\
\text { dermatitis }\end{array}$ & $5(8.3)$ & 7 (11.7) & 0.54 \\
\hline $\begin{array}{l}\text { History of allergic } \\
\text { rhinitis }\end{array}$ & $11(18.3)$ & $13(21.7)$ & 0.65 \\
\hline Food allergy & 7 (11.7) & $5(8.3)$ & 0.54 \\
\hline
\end{tabular}

Table 2) The absolute and relative distributions of daily and nocturnal cough rates in the children in the interventional group ( 60 subjects) and control ( 60 subjects) at the baseline (numbers in parentheses are

\begin{tabular}{|c|c|c|c|}
\hline Coughing rate & $\begin{array}{c}\text { Intervention } \\
\text { group }\end{array}$ & $\begin{array}{l}\text { Control } \\
\text { group }\end{array}$ & $P$ value \\
\hline \multirow{5}{*}{$\begin{array}{l}\text { Daily cough } \\
\text { None } \\
\text { Less than two days a } \\
\text { week } \\
\text { More than two days a } \\
\text { week, but not every } \\
\text { day } \\
\text { Every day } \\
\text { Frequently during } \\
\text { the day }\end{array}$} & 0 & 0 & \multirow[t]{5}{*}{0.38} \\
\hline & $3(5.0)$ & 0 & \\
\hline & $9(15.0)$ & $9(15.0)$ & \\
\hline & $39(65.0)$ & $41(68.3)$ & \\
\hline & $9(15.0)$ & $10(16.7)$ & \\
\hline \multirow{4}{*}{$\begin{array}{l}\text { Nocturnal cough } \\
\text { None } \\
\text { One to two times a } \\
\text { month } \\
\text { Three to four times a } \\
\text { month } \\
\text { More than once a } \\
\text { week }\end{array}$} & $10(16.7)$ & $4(6.7)$ & \multirow[t]{4}{*}{0.75} \\
\hline & $4(6.7)$ & 10 (16.7) & \\
\hline & 31 (51.6) & $33(55.0)$ & \\
\hline & $15(25.0)$ & $13(21.6)$ & \\
\hline
\end{tabular}

84

$48 \mathrm{~h}$, one week and two weeks after interventions, the daily cough and nocturnal cough of the intervention group decreased significantly compared with the control group $(\mathrm{p}<0.05$; tables 3 and 4).

Table 3) The absolute and relative distribution and intergroup comparison of the children's daily cough rates according to the time (numbers in parentheses are percentages)

\begin{tabular}{|c|c|c|c|}
\hline Daily cough rates & $\begin{array}{l}\text { Interventi } \\
\text { on group }\end{array}$ & $\begin{array}{l}\text { Control } \\
\text { group }\end{array}$ & $P$ value \\
\hline \multicolumn{4}{|c|}{$\begin{array}{l}48 \text { hours after research } \\
\text { interventions }\end{array}$} \\
\hline None & $9(15.0)$ & 0 & \multirow[t]{5}{*}{0.1} \\
\hline Less than two days a week & $2(3.3)$ & 0 & \\
\hline $\begin{array}{l}\text { More than two days a } \\
\text { week, but not every day }\end{array}$ & $22(36.7)$ & $21(35.0)$ & \\
\hline Every day & $25(41.7)$ & $37(61.7)$ & \\
\hline Frequently during the day & $2(3.3)$ & $2(3.3)$ & \\
\hline \multicolumn{4}{|l|}{$\begin{array}{l}\text { A week after research } \\
\text { interventions }\end{array}$} \\
\hline None & $35(58.3)$ & $2(3.3)$ & \multirow[t]{5}{*}{0.0001} \\
\hline Less than two days a week & 7 (11.7) & $2(3.3)$ & \\
\hline $\begin{array}{l}\text { More than two days a } \\
\text { week, but not every day }\end{array}$ & $14(23.3)$ & $50(83.4)$ & \\
\hline Every day & $4(6.7)$ & $6(10.0)$ & \\
\hline Frequently during the day & 0 & 0 & \\
\hline \multicolumn{4}{|l|}{ Two weeks after } \\
\hline $\begin{array}{l}\text { research interventions } \\
\text { None }\end{array}$ & $50(83.3)$ & 37 (61.6) & \multirow[t]{5}{*}{0.3} \\
\hline Less than two days a week & $4(6.7)$ & $10(16.7)$ & \\
\hline $\begin{array}{l}\text { More than two days a } \\
\text { week, but not every day }\end{array}$ & $6(10.0)$ & $13(21.7)$ & \\
\hline Every day & 0 & 0 & \\
\hline Frequently during the day & 0 & 0 & \\
\hline
\end{tabular}

Table 3) The absolute and relative distribution and intergroup comparison of the children's nocturnal cough rates according to the time (numbers in parentheses are percentages)

\begin{tabular}{|c|c|c|c|}
\hline Nocturnal cough rates & $\begin{array}{c}\text { Interven } \\
\text { tion } \\
\text { group }\end{array}$ & $\begin{array}{l}\text { Control } \\
\text { group }\end{array}$ & $P$ value \\
\hline \multicolumn{4}{|l|}{$\begin{array}{l}48 \text { hours after research } \\
\text { interventions }\end{array}$} \\
\hline None & $17(28.3)$ & $4(6.7)$ & 0.001 \\
\hline One to two times a month & 25 (41.7) & $23(38.3)$ & \\
\hline Three to four times a month & $12(20.0)$ & $29(48.3)$ & \\
\hline More than once a week & $6(10.0)$ & $4(6.7)$ & \\
\hline \multicolumn{4}{|l|}{$\begin{array}{l}\text { A week after research } \\
\text { interventions }\end{array}$} \\
\hline None & $41(68.3)$ & $11(18.3)$ & 0.0001 \\
\hline One to two times a month & $15(25.0)$ & 35 (58.3) & \\
\hline Three to four times a month & $4(6.7)$ & $14(23.4)$ & \\
\hline More than once a week & 0 & 0 & \\
\hline \multicolumn{4}{|c|}{$\begin{array}{l}\text { Two weeks after research } \\
\text { interventions }\end{array}$} \\
\hline None & $54(90.0)$ & $28(46.7)$ & 0.0001 \\
\hline One to two times a month & $6(10.0)$ & $31(51.6)$ & \\
\hline Three to four times a month & 0 & $1(1.7)$ & \\
\hline More than once a week & 0 & 0 & \\
\hline
\end{tabular}

In intragroup comparison, there was a significant difference between the cough rates of children at 
four studied times in the intervention and control group $(\mathrm{p}<0.05)$.

Comparing the one and two weeks after the interventions with baseline, the cough rate was almost the same in the studied groups, however, the number of children whose cough rates dropped $48 \mathrm{~h}$ after intervention was significantly greater in the intervention group than in the control group, and administration of caffeine plus salbutamol reduced the rate of cough in children in a shorter time.

\section{Discussion}

The findings of this study showed that $48 \mathrm{~h}, 1$ week and 2 weeks after the intervention, the daily and nocturnal cough rates in the intervention group decreased significantly compared with the control group. Therefore, it can be concluded that caffeine has been able to cause differences between the intervention group and the control group and decreased the daily and nocturnal cough rates $48 \mathrm{~h}$, 1 week and 2 weeks after the intervention in subjects.

The results of the intra-group comparison of the daily and nocturnal cough rates of children indicate that, although one week and two weeks after the research interventions compared with the baseline, the decrease in daily and nocturnal cough rates in the studied groups was almost the same, however, the number of children whose daily and nocturnal cough rates decreased within $48 \mathrm{~h}$ after interventions was significantly more in the intervention group than in the control group and simultaneous administration of caffeine and salbutamol resulted in a reduction in the daily and nocturnal cough rates of children.

The findings of the present study on the changes in daily and nocturnal cough rates can be explained based on theoretical, rational and justifiable knowledge. Coughing is one of the most important defensive mechanisms in the upper airways to clean bronchi, trachea and larynx from mucus, discharge, or foreign material, which can be reflexive or voluntary. Through the day, due to the greater need to keep the airways to supply of needed oxygen based on the level of activity, daily cough is more likely, and although the increase in daily cough rates for an individual is unpleasant, nocturnal cough can also reduce the quality of sleep in a child [24]. Accordingly, since caffeine, in addition to its antiinflammatory effect caused by inhibition of TNF $\alpha$ cytokine (alpha necrosis factor) and mediated by cyclic adenosine monophosphate/protein kinase A, and also the ability of stimulate respiratory center and increase the speed and depth of respiration, is associated with advantage, including dilated bronchus as well as facilitating muscle function and increasing the overall function of a muscle, in particular respiratory muscles [16-19], its positive effect in reducing daily and nocturnal cough can be explained by theoretical knowledge.

The results of the studies by Welsh et al. [17], de Boer et al. [25] and Köroğlu et al. [26] also support the findings of the present study in a significant reduction in daily cough and nocturnal cough by caffeine as an independent variable. The effectiveness of caffeine on coughing in animal models has also been studied, including the study by Tolmacheva \& Kireyev on the cough induced by citric acid $10 \%$ in the rat model. According to the results of these researchers, after caffeine use, positive therapeutic results have been found to reduce coughing attacks in $79 \%$ of animal samples [27].

In previous studies, there has been no significant difference in daily and nocturnal cough, and most studies reported the changes in cough rates in general. Accordingly, it can be claimed that studying variations in daily and nocturnal cough is one of the positive points of the present study.

Another finding of the present study is that coadministration of salbutamol and caffeine shortens the time taken for improvement of daily and nocturnal cough in children. One of the main benefits and importance of this finding is the fact that today one of the goals of health care systems is to treat it as soon as possible. The increased efficacy of combined drug regimens has been reported in numerous studies, such as Ahmadi et al. [28], Ranjbar et al. [29], Roohi Broujeni et al. [30] and Raeessi et al. [31].

Despite positive effects, this study also had some limitations that might affect the results of the study. Some of these limitations are as follows: the possible use of some supportive interventions, such as fumigation, warming and moisturizing the place patient is living, herbal remedies and traditional interventions, etc. by families, consuming food or drink containing caffeine by children during study, changes in weather conditions, temperature and humidity during the study period, as well as the use of disinfectants in the research that are usually misleading and stimulating and cause a different reaction in each individual.

According to the results of this study and considering the probable confirmation of these results in other similar studies, the researchers suggest to study the effect of prescribing caffeine alone in future studies on cough in children. Also, due to the mechanism of caffeine effect, by coadministration of this drug with salbutamol, the efficacy in the treatment of wheeze is scientifically also expected, therefore, the researchers recommend that in subsequent studies, the effect of co-administration of caffeine with salbutamol, as well caffeine alone, on wheeze in children's should be investigated.

All these considerations into account, as well as availability, affordability, cost-effectiveness, efficacy 
Effect of Caffeine on Coughing in Children Aged 3-36 Months ... rate, low side effects and positive effects of caffeine therapy in reducing daily and nocturnal cough coughing in children 3-36 months, the effectiveness of this combined therapy in the treatment of children with cough can be used.

\section{Conclusion}

Caffeine can reduces daily and nocturnal cough in children aged 3-36 months, and administration of caffeine plus salbutamol decreases daily and nocturnal cough of children in a shorter time.

\section{Acknowledgements}

This study is extracted from a Pediatric medical assistant thesis of the faculty of medicine of Yasuj University of Medical Sciences, which was funded by this university. We would like to thank from the efforts of the staff of the Faculty of Medicine and the deputy director of research and technology at Yasuj University of Medical Sciences, staff of Shahid Mofateh Pediatric Clinic affiliated to Yasouj University of Medical Sciences, the subjects, including 3-36 months children and their families and all who helped us in this study.

\section{Ethical permissions}

This study was approved by the Research Ethics Committee (Ethics code IR.YUMS.REC.1394.172) and registered at Iranian registry of clinical trials (IRCT2016041727444N1).

\section{Conflicts of interests}

None declared.

\section{Authors' contribution}

Marjan Tagrian Esfahani (first author), writing introduction/main researcher (25\%); Kambiz Keshavarz (second author), writing introduction/main researcher/ writing discussion (25\%); Ali Keshtkari (third author), writing introduction/main researcher (5\%); Hossein Sadeghi Mansourkhani (fourth author), writing introduction/main researcher (10\%); Mehdi Akbartabar Toori (fifth author), writing introduction/methodologist (5\%); Mohammad Zoladl (sixth author), writing introduction/analyst/ writing discussion (30\%).

\section{Funding/Support}

The Vice-Chancellor for Research and Technology of Yasouj University of Medical Sciences supported this research.

\section{References}

1- Kliegman RM, Stanton B, Behrman RE, St Gemem JW, Schor NF. Nelson textbook of pediatrics. 20 th Edition. Philadelphia: Elsevier; 2016.

2- McNamara PS, Smyth RL. The pathogenesis of respiratory syncytial virus disease in childhood. Br Med Bull. 2002;61(1):13-28.

3- Simoes EA. Respiratory syncytial virus infection. Lancet. 1999;354(9181):847-52.

4- Boyce TG, Mellen BG, Mitchel EF, Wright PF, Griffin MR. Rates of hospitalization for respiratory syncytial virus infection among children in Medicaid. J pediatr. 2000;137(6):865-70.

5- Shay DK, Holman RC, Newman RD, Liu LL, Stout JW, Anderson LJ. Bronchiolitis-associated hospitalizations among US children, 1980-1996. JAMA. 1999;282(15):14406.

6- Bloemers BL, van Furth AM, Weijerman ME, Gemke RJ, Broers CJ, van den Ende K, et al. Down syndrome: a novel risk factor for respiratory syncytial virus bronchiolitis-a prospective birth-cohort study. Pediatrics. 2007;120(4):e1076-81.

7- Ogra PL. Respiratory syncytial virus: the virus, the disease and the immune response. Paediatr Respir Rev. 2004;5(Suppl A):S119-26.

8- Hall CB. Respiratory syncytial virus and parainfluenza virus. N Engl J Med. 2001;344(25):1917-28.

9- Falsey AR, Cunningham CK, Barker WH, Kouides RW, Yuen JB, Menegus M, et al. Respiratory syncytial virus and influenza A infections in the hospitalized elderly. J Infect Dis. 1995;172(2):389-94.

10- Tian M, Zhao D, Wen G, Shi S. The correlation factor about respiratory syncytial virus bronchiolitis and postbronchiolitis wheezing in infant. Zhonghua Shi Yan He Lin Chuang Bing Du Xue Za Zhi. 2009;23(5):371-4. [Chinese]

11- García CG, Bhore R, Soriano-Fallas A, Trost M, Chason R, Ramilo O, Mejias A. Risk factors in children hospitalized with RSV bronchiolitis versus non-RSV bronchiolitis. Pediatrics. 2010;126(6):e1453-60.

12- Meyers DA, Marsh DG. Report on a national institute of allergy and infectious diseases-sponsored workshop on the genetics of total immunoglobulin E levels in humans. J Allergy Clin Immunol. 1981;67(3):167-70.

13- Horak E. Wheezing in infants and toddlers: new insights. Wien klin Wochenschr. 2004;116(1-2):15-20. [German]

14- Barnes PJ, Greening AP, Neville L, Timmers J, Poole GW. Single-dose slow-release aminophylline at night prevents nocturnal asthma. Lancet. 1982;1(8267):299-301.

15- Wheeler DS, Wong HR, Shanley TP. The respiratory tract in pediatric critical illness and injury. London: Springer Science \& Business Media; 2008.

16- Tschudy MM, Arcara KM. The Harriet Lane Handbook. 19th Edition. St. Louis: Mosby Elsevier; 2012.

17- Welsh EJ, Bara A, Barley E, Cates CJ. Caffeine for asthma. Cochrane Database Syst Rev. 2010;(1):CD001112. 18- Martin RJ, Fanaroff AA, Walsh MC. Fanaroff and Martin's Neonatal-perinatal medicine: diseases of the fetus and infant. 9th Edition. St. Louis: Mosby Elsevier; 2011.

19- Collomp K, Candau R, Millet G, Mucci P, Borrani F, Prefaut C, De Ceaurriz J. Effects of salbutamol and caffeine ingestion on exercise metabolism and performance. Int J Sports Med. 2002;23(8):549-54.

20- Schwartz J, Weiss ST. Caffeine intake and asthma symptoms. Ann Epidemiol. 1992;2(5):627-35.

21- Sigurs N, Gustafsson PM, Bjarnason R, Lundberg F, SchmidtS, Sigurbergsson F, Kjellman B. Severe respiratory syncytial virus bronchiolitis in infancy and asthma and allergy at age 13. Am J Respir Crit Care Med. 2005;171(2):137-41.

22- Bont L, Steijn M, van Aalderen WMC, Brus F, Draaisma JT, Van Diemen-Steenvoorde RA, et al. Seasonality of long term wheezing following respiratory syncytial virus lower respiratory tract infection. Thorax. 2004;59(6):512-6.

23- Abbasi R, Asadi SH, Keshavarz K, Zoladl M, Kazerooni S, Sharafian S, Mohammadhossieni Z. Lack of effect of zinc sulfate on wheezing after bronchiolitis in infants less than 
87

two years. Armaghan-e-Danesh. 2014;19(7):572-9. [Persian]

24- Karimi A, Fahimzadeh SA, Armin Sh. Chronic cough and how to deal with it. J Med Counc Iran. 2010;28(4):420-37. [Persian]

25- de Boer A, van de Worp WRPH, Hageman GJ, Bast A. The effect of dietary components on inflammatory lung diseases-a literature review. Int J Food Sci Nutr. 2017;68(7):771-87.

26- Köroğlu ÖA, MacFarlane PM, Balan KV, Zenebe WJ, Jafri A, Martin RJ, Kc P. Anti-inflammatory effect of caffeine is associated with improved lung function after lipopolysaccharide-induced amnionitis. Neonatology. 2014;106(3):235-40.

27- Tolmacheva KS, Kireyev IV. Cough model in the rats induced by $10 \%$ citric citric acid [Internet]. Kharkiv: Ministry of Public Health of Ukraine, National University of Pharmacy; 2016 [cited 2017 Oct 12]. Available from: https://bit.ly/2G1PzXV
Tagrian Esfahani M. et al.

28- Ahmadi Z, Joz Mohtashami M, Seyed Fatemi N, Haghani H. Study of realationship between social support and parents satisfaction of provided care for premature infants in selected hospitals of Tehran University of Medical Sciences. J Pediatr Nurs. 2015;2(2):39-48. [Persian]

29- Ranjbar M, Panahi A, Heidari Farah Sh, Nekoozadeh S. Comparison study of therapeutic effect of dextrometorphan and essence of Thyme (Zatara Multiflorian) in acute and non-productive cough. Razi J Med Sci. 2015;22(134):101-6. [Persian]

30- Roohi Broujeni H, Ganji F, Roohi Broujeni P. The effect of combination of Zingeber and Althea officinalis extracts in acute bronchitis-induced cough. J Shahrekord Univ Med Sci. 2009;10(4):38-43. [Persian]

31- Raeessi MA, Aslani J, Raeessi N, Gharaie H, Karimi Zarchi AA, Raeessi F. Honey plus coffee versus systemic steroid in the treatment of persistent post-infectious cough: a randomised controlled trial. Prim Care Respir J. 2013;22(3):325-30. 